\title{
Diseño de método presupuestal para compañías de servicios petroleros
}

Budget design projections in oil companies

Projeto de método orçamental para empresas

de serviço de petróleo

Roberto C. Elizalde

Universidad Internacional Iberoamericana

(UNINI), Campeche, México.

E-mail: roberto.elizalde@weatherford.com

Fecha de recepción: 07/07/2020 Fecha de aceptación:18/01/2021
Palabras clave

- Proyecciones

- Estado de resultados

- Incremento absoluto

- Mínimos cuadrados

\section{Resumen}

La presente investigación fue realizada para determinar el método de proyección más adecuado y preciso que se utilizará en las proyecciones financieras, principalmente en la elaboración del estado de resultados donde se registran los ingresos, costos y gastos de una empresa de servicios petroleros. Con este objetivo se ha recopilado la información suficiente acorde a la presentación de los resultados de los tres últimos años para que en base a ello se apliquen los métodos de proyección y luego se establezca la diferencia entre ellos. El texto se considera como un estudio no experimental puesto que los datos reales que se obtengan no serán modificados. Cabe mencionar también que los cálculos realizados se efectuaron mediante Microsoft Excel. Entre los métodos de proyección que se evaluaron se encuentran el método de incremento absoluto, de incremento porcentual, de promedio móvil y el método de mínimos cuadrados, por lo que al realizar un comparativo entre ellos es posible hacerlo de forma vertical y horizontal. Cabe destacar que en ambas comparaciones se determina que el método de incremento absoluto es el más preciso al realizar proyecciones presupuestales, seguido del método de mínimos cuadrados, por lo que tanto el método de incremento porcentual y como el promedio móvil ponderados son menos precisos. 
Keywords

- Projections

- Income statement

- Absolute increase

- Least squares

- Profit and losses

Palavras-chave

- Projeções

- Demonstração de resultados

- Incremento absoluto

- Mínimos quadrados

\section{Abstract}

The objective of this research work is to determine the most appropriate and accurate projection method to be used in financial projections, mainly in the elaboration of the statement of income, in which the incomes, costs and expenses of an oil company are recorded. In order to achieve this, information about the results statement (profit and losses summaries) of the last three years has been collected to apply different statistical methods and compare the results to determine the differences among them, and therefore be able to decide which the best statistical method is. The present investigation is considered a non-experimental study since the actual data obtained will not be modified. Moreover, all the calculations were made using Microsoft Excel. The projection methods evaluated include the method of absolute increase, percentage increase, moving average and the method of least squares. It is possible to compare them both vertically and horizontally. Both types of comparison have shown that the absolute increase method is the most accurate one when making budget projections, followed by the method of least squares. Consequently, the percentage increase and the moving average methods analyzed are the least accurate ones.

\section{Resumo}

Esta pesquisa foi realizada com 0 objetivo de determinar 0 método de projeção mais adequado e preciso para utilizar nas projeções financeiras de uma empresa prestadora de serviços de petróleo, principalmente na elaboração das demonstrações de resultados onde são registrados tanto os rendimentos quanto os custos e despesas. Para este fim se recolheu a informação necessária das apresentações dos resultados dos últimos três anos para que, com base nelas, sejam aplicados os métodos de projeção e posteriormente, estabelecer a diferença entre eles. Esta pesquisa é considerada um estudo não experimental já que os dados reais obtidos não sofreram modificações. Nesta oportunidade os cálculos foram realizados no Microsoft Excel. Os métodos de projeção que foram avaliados são: 0 método do incremento absoluto, 0 do aumento percentual, 0 da média móvel e 0 dos mínimos quadrados. Estes métodos foram comparados de maneira vertical e horizontal e, em ambas as comparações, determinou-se que ao fazer projeções de orçamento 0 método do incremento absoluto é o mais preciso, seguido pelo método dos mínimos quadrados. Assim, tanto o método de aumento percentual quanto o método de média móvel ponderada são menos precisos. 